\title{
The Application Potential of Eco-Efficiency for Greening Company
}

\author{
Lukman Eka Prasaja $^{1 *}$, Hadiyanto ${ }^{2}$ \\ ${ }^{1}$ Master Program of Environmental Science, School of Postgraduate Studies, Diponegoro University, Semarang-Indonesia \\ ${ }^{2}$ Departement of Chemical Engineering, Faculty of Engineering, Diponegoro University, Semarang - Indonesia
}

\begin{abstract}
Eco-Efficiency emerged in the 1990s as a measure of "the efficiency that ecological sources use to meet human needs." As a tool in economic and environmental integration, Eco-efficiency needs to be promoted further so that regulation in government and industrial management can include it as an important instrument. This paper provides several approaches that can help various industries to develop effective ecoefficiency principles. The approach used is to maximize the role of the Steering Committee of the company's internal environment. Utilization of natural resources such as water, forests, mines and energy needs need to be balanced with Eco-Efficiency so that natural exploitation can be well controlled so that sustainable development aspired by the world can be realized.
\end{abstract}

\section{Introduction}

The growing industrial development has a positive impact on growth Economy in Indonesia. However, the development of industry is also not free from negative impacts Caused to environmental sustainability. Waste and also pollutants produced by various industrial activities are problems that can lead to degradation environment. Such conditions are certainly more worrying.

Natural Resources exist with various forms and distribution. Some can be renewed, others are nonrenewable. There are also areas that are rich in natural resources, otherwise there are areas that are poor in resources. It all seems to form a balance that should be maintained. Abundant areas of certain natural resources can meet the needs of the under-developed areas. Nonrenewable resources are sought to balance with the principles-based management of eco-efficiency and sustainability. So it is with other natural resources. In essence, the sustainability of natural resources can be achieved with the use of the eco-efficient, manage it with sustainable and insightful guidelines [1].

Public awareness of Efforts to conserve the environment itself is also still low, while government policy in Dealing with environmental degradation due to the activities of the industrial sector is still in question. One effort Overcoming the problems of industrial environmental degradation is by applying the concept Sustainable development as a paradigm in industrial sector development, be it industry Large, medium and SMEs [2].

The world's financial and economic problems caused a crisis that has caused economic stagnation in many countries. One way to overcome the crisis is to re-adjust the growth of green economy.

The concept of eco-efficiency could have been much adopted by the world's companies in making improvements and prevention of industrial pollution to the environment [3].

There are many concepts related to the environment, such as environmental management, environmental conservation, sustainable development, natural resource conservation, eco-efficiency and much more. When read at a glance, the concepts have almost no significant difference, but in reality each term has a different emphasis. In order to know the meanings and also the interrelationship between the concepts, it is necessary to study theoretically related to the concepts and also the relationship [4].

Eco-efficiency improves business and environmental performance, and helps companies get out in front of market and regulatory trends, to reduce costs, to gain competitive advantage and to ensure long-term profitability and sustainability. Being efficient is always a high priority for every company. Eco-efficiency is suitable to be applied on green industry conceptual, because it can synergize economic and environmental aspects. Application of eco-efficiency will lead to competitiveness, environmental sustainability, and quality of life better

In this essay will be presented notions in every concept that is often used in the discussion of environmental problems. In addition, it will also disclose the differences and continuity between concepts until it can be drawn a conclusion that will be accompanied by case examples. Hope to be achieved by the author of this essay is the reader can know the position of each concept

* Corresponding author: bungekaprasaja@gmail.com 
in environmental problems, so that can be drawn a conclusion that is easy to understand.

\section{Methods}

The proven principle of eco-efficiency in some business approaches, to reduce losses from a variety of environmental damage effects and financial losses, becomes an opportunity that can be used in a variety of industry sectors. In this paper the method used is to provide various kinds of approaches that allow for some types of industries to be performed

\subsection{Principle of eco-efficiency}

Eco-efficiency is management philosophy that aims at minimizing ecological damage while maximizing efficiency of the firm's production processes, such as through the lesser use of energy, material, and water, more recycling, and elimination of hazardous emissions or by-products [5].

Since the 1960 s, corporations have witnessed an era of compliance marked by the promulgation of numerous environmental laws, followed by an era of voluntary environmental management to help prevent pollution, emergencies and environmental disasters such as the Exxon Valdez spill and the Bhopal catastrophe. In the developed world, many corporations are now implementing voluntary environmental management systems (EMS) to prevent and minimize environmental impacts. However, site location, local environmental regulations, and the level of legal enforcement will often dictate the stage of a company's environmental management or compliance [6].

An EMS can be developed according to various published guidelines but the ISO 14000 series of standards developed by the International Standardization Organization (ISO) are the most internationally recognized. A few thousand companies across the world have already obtained their ISO 14001 EMS registration and many more are in the process of becoming registered. Although the ISO standard is not prescriptive, it requires companies to have a formal EMS that includes: [6]

- Documented environmental policy honored by senior management;

- Documented procedures to prevent or minimize all significant environmental impacts;

- Employee environmental training program to ensure environmental awareness and respect of environmental regulations and documented EMS procedures;

- Regular internal and external audits of the EMS; and,

- an annual management review of the system.

The implementation process of eco-efficiency adopting from cleaner production usually consists of 5 basic steps:

(1) Planning and organizing the resources;
(2) Analyzing the research object to identify the wastes and its characteristics;

(3) Proposing the possible solutions/methods;

(4) Studying the feasibility of the solution;

(5) Implementing the chosen solution.

However, cleaner production or eco-efficiency is not a one-time-project. In other to achieve the sustainable development and long-term benefits, the factory needs a system to maintain and improve continuously $[5,7]$.

\subsection{Steering committee eco-efficiency for green company}

This study was conducted on a management practice for green company as a case study. This formula is adapted from what has been done by rice companies in Vietnam. The commitment from the leader is very important, which could support establishing the cleaner production team. This team usually has the scale depending on the organization size. However, it should consist of members who have knowledge and skills as presented in Table 1. [7].

This organizational management approach can be used in several sectors related to the possible implementation of eco-efficiency.

Table. 1. Eco-Efficiency Team Formulation

\begin{tabular}{|c|c|c|}
\hline Member & $\begin{array}{l}\text { Required knowledge and } \\
\text { skills }\end{array}$ & $\begin{array}{l}\text { People in } \\
\text { charge } \\
\text { (suggestive) }\end{array}$ \\
\hline Team leader & $\begin{array}{lr}\text { Decision } & \text { Making } \\
\text { Techniques. } & \text { Leadership. } \\
\text { Project Management }\end{array}$ & $\begin{array}{l}\text { Vice } \\
\text { Director }\end{array}$ \\
\hline Member 1 & $\begin{array}{l}\text { Environmental and energy } \\
\text { use requirements in the } \\
\text { processing product. Programs } \\
\text { and applications related to } \\
\text { environmental and energy } \\
\text { consumption management. } \\
\text { The concept of } \\
\text { environmental management } \\
\text { systems }\end{array}$ & $\begin{array}{l}\text { General } \\
\text { Manager }\end{array}$ \\
\hline Member 2 & $\begin{array}{l}\text { The process of financial } \\
\text { decision making. Risk } \\
\text { management. } \\
\text { Cost-benefit analysis of the } \\
\text { selected solution }\end{array}$ & $\begin{array}{l}\text { Finance and } \\
\text { accounting } \\
\text { staff }\end{array}$ \\
\hline Member 3 & $\begin{array}{l}\text { Production processes. The } \\
\text { environmental measurement, } \\
\text { control and assessment } \\
\text { process. Industrial and } \\
\text { systems engineering }\end{array}$ & $\begin{array}{l}\text { Technical } \\
\text { staff }\end{array}$ \\
\hline
\end{tabular}




\section{Approach for implementation of the principle of eco-efficiency for green industry}

This paper will explain the approach that can be used by various types of industries in support of eco-efficiency, it is important to realize the successful implementation in the green economy. Various natural resource assets in Indonesia encourage people to use as much as possible. This is very natural because people always feel not enough for the needs of life, so that human exploitation of natural resources. In order for the sustainability or potential of natural resources to exist, the following ways are required:

- Inventory and evaluation of natural resources need to be improved to better understand the utilization of natural resources

- In the exploitation and exploration of natural resources should be used appropriate technology appropriate, so that the potential of natural resources can be maintained.

- In the implementation of development should always be held a careful assessment of its impact on the environment.

- Rehabilitation of natural resources is done through an integrated approach.

- Utilization of natural resources of coastal areas, sea and air areas needs to be improved without undermining the quality and environmental sustainability.

Each development activity always produces a by product to the environment, that is industrial pollution as part of the construction machinery discharges waste into the environment. The process can not be avoided and the size depends on the nature of the goods produced. Although pollution always occurs, it can be reduced to a minimum.

\subsection{Eco-efficiency principle in forest utilization}

Forest utilization should use the principle of ecoefficiency. Illegal logging should be stopped. Deforestation should be carried out under the principle of eco-efficiency by breeding, selective logging, and reforestation. The objectives of reforestation and forest rehabilitation are as follows:

a. Increase the sustainability of forests, soil, and water

b. Expand the supply of valuable raw materials for the community.

c. Rescue the results of development efforts in the field of irrigation.

Forest conservation efforts include the following:

Felling trees is selective and replaces trees with trees that have an important role for the environment and the economy

- Balance between logging and reforestation should be sought
- Deforestation of forest functions as a preservative of water sources, soil, and recreation areas should be encouraged.

\subsection{Eco-efficiency principle in mining utilization}

Mining goods are non-renewable natural resources. The principle of mine utilization eco-efficiency can be done with the following steps:

a. Savings in usage by always remembering the next generation

b. Exports mining materials as finished or semifinished goods.

c. Conducting investigations and research to find new mining areas

d. Cultivated substitute material. For example the use of fuel is replaced with solar, gas or alcohol

\subsection{Eco-efficiency principle in water utilization}

Water conservation efforts are carried out in the following manner:

a. To maintain the existence of forests so that springs are not dry, especially forests in the upper river area

b. Keep the river water from being polluted. The disposal of industrial waste into the river must be neutralized first

c. Keep the well water clean. For example, keep the distance between wells and landfills at least 10 meters

d. Prevent the disposal of nuclear waste or industrial wastewater directly into the sea. Avoid leaks on oil tanker ships. Avoids carelessness, such as collisions between tankers and does not dispose of waste and waste into the sea

\subsection{Eco-efficiency principle in manufacture industry}

Unused materials and energy in a production process system will be wasted into waste and lead to increased social costs for further processing. Therefore, it is necessary step-step implementation of eco-efficiency principles in the industry as follows:
a. Minimize the use of raw materials and energy
b. Minimize the release of toxic waste into the environment
c. Produce recyclable products
d. Utilization of Renewable Resources
e. Able to produce durable products

\subsection{Eco-efficiency principle in meeting energy source needs}

Various human activities require energy such as coal, petroleum, geothermal, hydrocarbon, water, sunlight, wind, and waves. The current global problem is the 
diminishing of world petroleum reserves, while the need for fuel should always be available. The application of the principle of eco-efficiency in meeting the needs of fuel, among others: the use of alternative renewable energy sources such as wind power, sunlight, water, biomass, and organic materials.

a. Wind power

Wind power is generated by windmills to pump water with 5 liters of discharge used for daily necessities and agricultural needs. In the principle of eco-efficiency, wind power is useful to replace the energy of fuel pumping windmills.

b. Solar energy

Indonesia is actually a country that is very rich in solar energy because of Indonesia's position on the equator. Solar energy is a very potential alternative energy. This energy can be used for power generation to replace the water energy to generate electricity in megawatt level because the solar heat is able to supply more than 219,000 thousand billion $\mathrm{kWh}$ of energy every year. In addition to being utilized as a powerhouse, solar energy can also be used to heat the green house and dryer energy of agricultural products.

c. Water

Utilizing water as a source of power generation has been implemented by the Indonesian government on a large scale. But the actual use of water as a power plant can also be done alone by remote communities where there are small water sources, so that people dependence on electricity supply from electrical supply industry can be reduced by utilizing natural resources in their own.

d. Biomass and Organic Waste Materials

Agricultural biomass, especially agro-industry waste is an alternative source of energy, in lieu of oil and gas fuels. Thus the utilization will have a positive impact, both for business and for the welfare of the environment as a whole. In Indonesia, agro-industry wastes can be used as alternative energy sources such as charcoal briquettes, biogas, biodiesel and acetone, butanol, and ethanol.

\section{Conclusion}

Eco-Efficiency is very necessary to be done by various sector of Industry, it is important as effort to keep exploitation of natural resources. Utilization of forests, water and energy needs to be well managed, ecoefficiency can be an appropriate approach to be consistent with the principle of sustainable development. The results of this paper are expected to provide a stimulus of initial views by policy makers, so that it can be an action that gives a positive impact in environmental management seems to be government, especially on policy and finance. It needs radical action: one action, one large funding and strong institutional collaboration.

\section{References}

1. Environmental Protection Agency (EPA), United States, "Green Servicizing: Building a More Sustainable Economy”, Internal working draft, EPA, Washington, D.C, (2009)

2. FORA, Green Business Models in the Nordic Region: A key to promote sustainable growth", Green paper for the Nordic Council of Ministers, Copenhagen, (2010)

3. Measuring Eco-efficiency: A Guide to Reporting Company Performance. (2000).

4. World Business Council for Sustainable Development. Mickwitz, Per et al. "Regional Ecoefficiency Indicators E A Participatory Approach". Journal of Cleaner Production, Volume 14: 16031611, (2006)

5. L. Kenneth, Mu'lholland, Identification of Cleaner Production Improvement Opportunities. A joint publication of the American Institute of Chemical Engineers and John Wiley \& Sons, Inc, (2006)

6. Phil Ribiel. Eco-Efficiency: The Next Step Toward Sustainable Development, (2015)

7. Tran Cuoc. Feasibility of cleaner production for Vietnam rice processing industry. 13th Global Conference on Sustainable Manufacturing Decoupling Growth from Resource Use, (2016) 